\title{
Federacja Rosyjska wobec Brexitu - szanse i zagrożenia
}

\section{The Russian Federation and Brexit - Chances and Threats}

\section{- Abstrakt •}

Przedmiotem mojego zainteresowania jest przeanalizowanie najważniejszych uwarunkowań i zależności dotyczących stosunku Federacji Rosyjskiej do Brexitu w wymiarze politycznym, ekonomicznym oraz militarnym. Głównym celem niniejszych rozważań jest próba odpowiedzi na pytanie, czy wyjście Wielkiej Brytanii z Unii Europejskiej może stać się dla Rosji szansą na realizację swoich celów politycznych, gospodarczych i militarnych, czy jednak będzie zagrożeniem dla jej interesów międzynarodowych.

$\mathrm{Na}$ wstępie zamierzam opisać wymiar polityczny Brexitu dla Rosji, który jest związany z próbą szukania przez ekipę rządzącą na Kremlu oraz związanych z nią dziennikarzy i publicystów przyczyn, dla których Brytyjczycy podjęli $\mathrm{w}$ referendum przedmiotową decyzję. Chciałbym przedstawić także hipotezę, że za sprawą głosowania w Wielkiej Brytanii Moskwa ponownie stała się liczącym się graczem na arenie międzynarodowej po aneksji Krymu i wojnie we wschodniej Ukrainie, czego dowodzi m.in. nasilona amerykańsko-rosyjska współpraca przy rozwiązaniu konfliktu syryjskiego. W dalszej części tekstu poruszam problem sytuacji gospodarczej Rosji i możliwych implikacji Brexitu dla funkcjonowania rosyjskiej ekonomii. Ponadto przybliżam wymiar militarny Brexi-

\section{- Abstract •}

The subject of my interest is to analyze the most important conditions and dependencies regarding the attitude of the Russian Federation towards Brexit in the political, economic and military dimension. The main purpose of these considerations is an attempt to answer the question of whether Britain's exit from the European Union may become a chance for Russia to achieve its political, economic and military goals or a threat to its international interests.

At the outset, I intend to describe the political dimension of Brexit for Russia, which is related to the attempts of the Kremlin's government and journalists to find out why the British have made the decision in the referendum. I would also like to present a hypothesis that because of the vote in the UK, Moscow has once again become a major player in the international arena after the annexation of Crimea and the war in eastern Ukraine, as evidenced by the US-Russian cooperation in resolving the Syrian conflict. In the further part of the text, I address the problem of Russia's economic situation and the possible implications of Brexit on the functioning of the Russian economy. In addition, I am introducing the military dimension of Brexit for Russia, which is related to the findings of the NATO summit in Warsaw 
tu dla Rosji, wiążący się z ustaleniami szczytu NATO w Warszawie z lipca 2016 r., dotyczący wzmocnienia wojsk Sojuszu na tzw. flance wschodniej.

W podsumowaniu postaram się nakreślić, czy Brexit może okazać się dla Rosji w dłuższej perspektywie czasowej szansą, czy zagrożeniem dla jej bieżących interesów politycznych, gospodarczych i wojskowych.

Słowa kluczowe: Federacja Rosyjska; Brexit; Wielka Brytania; Stany Zjednoczone Ameryki; Syria; UE in July 2016, regarding the strengthening of the Alliance's forces on the so-called Eastern flank.

In summary, I will try to outline whether Brexit may be a long-term opportunity or a threat to Russia, considering its current political, economic and military interests.

Keywords: Russian Federation; Brexit; Great Britain; United States of America; Syria; EU

\section{Wprowadzenie}

Omawiając stanowisko Rosji wobec wyjścia Wielkiej Brytanii z Unii Europejskiej i możliwych implikacji takiego rozwiązania dla pozycji tego wschodniego mocarstwa w aspekcie wewnętrznym i międzynarodowym, należy przyjrzeć się kilku zasadniczym czynnikom, za których sprawą zdecydowałem się podjąć niniejszy temat. Obecne wydarzenia na świecie są ściśle powiązane z realizowaną przez rosyjskiego prezydenta Władimira Putina oraz jego otoczenie próbą odzyskania wcześniej posiadanego statusu Rosji, którym cieszyła się szczególnie za czasów Związku Radzieckiego. Służy temu zarówno aneksja Krymu, wojna we wschodniej Ukrainie, jak i powrót po ponad 20 latach przerwy na Bliski Wschód. Dla rosyjskich władz i elit politycznych referendum brytyjskie w sprawie wystąpienia z UE stało się kolejną okazją do realizowania celów geostrategicznych. W związku z powyższym celem mojej analizy jest próba odpowiedzi na pytanie: na ile Brexit może okazać się szansą - lub też zagrożeniem - dla sytuacji wewnętrznej Rosji oraz jej interesów globalnych. W dobie wymienionych już częściowo wyzwań, stojących przed Rosją, i zawirowań wewnętrznych na płaszczyźnie ekonomicznej Brexit może stać się dla Rosji nową, skuteczną okazją do przełamania izolacji międzynarodowej i powrotu tego kraju do grona mocarstw, czynnie wpływających na globalne konfiguracje międzynarodowe. Omawiany scenariusz może zostać zmaterializowany również za pomocą odpowiedniego wspierania wyborów parlamentarnych i prezydenckich w ważniejszych państwach świata. $\mathrm{Na}$ ich wynik wpływa znacząco przybierający różnorakie formy światowy kryzys imigracyjno-uchodźczy, który doprowadził już do zmiany konfiguracji władzy w Niemczech, we Francji i w USA poprzez wypowiedzi zachodnich zwolenników współpracy z Moskwą, uznających ją za mocarstwo, bez którego udziału rozwiązanie istotniejszych kwestii globalnych nie jest 
możliwe. Brexit może - choć nie musi - okazać się istotnym krokiem prowadzącym do realizacji zamierzeń Kremla w powyższym aspekcie. Przybliżając proces wyjścia Wielkiej Brytanii ze Wspólnoty Europejskiej i reakcje rosyjskie w niniejszej materii, warto prześledzić ponadto kwestie militarne, powiązane głównie z ustaleniami warszawskiego szczytu NATO z lipca 2016 r., gdyż w dłuższej perspektywie czasowej wzrost znaczenia Sojuszu Północnoatlantyckiego w Europie w sposób oczywisty prowadzi do storpedowania sformułowanych wyżej celów rosyjskiej dyplomacji.

\section{Wymiar polityczny Brexitu dla Rosji}

Poddając analizie reakcje zarówno władz rosyjskich, jak i mediów tego kraju na omawiane wydarzenie, należy przyjrzeć się kilku kwestiom. Po pierwsze, sprzeciw większości Brytyjczyków wobec UE stanowi dla Kremla okazję do pokazania światu, że idea integracji europejskiej okazuje się nieskuteczna we współczesnych wyzwaniach międzynarodowych. Kreml, który od zakończenia II wojny światowej deklarował gwałtowny sprzeciw wobec pojawienia się koncepcji integracyjnych (Udziat mocarstw zachodnich w konferencji paryskiej..., 1951, s. 3), traktuje każdy wyłom w strukturach UE jako sukces własnej polityki, opierającej się na akcentowaniu kwestii wewnętrznych i suwerennych decyzji społeczności krajów członkowskich. Generalnie rzecz ujmując, Kreml wyznaje publicznie pogląd, że to wyłącznie w gestii suwerennych państw narodowych powinno być prowadzenie polityki na arenie wewnętrznej i zewnętrznej, a sama forma integracji w ramach UE nie przynosi wymiernych rezultatów politycznych. Jeden z głównych kremlowskich propagandzistów, Dimitrij Kisielow, szef państwowego koncernu medialnego „Rossija Sewodnia”, powiedział wyraźnie, że „Brytyjczycy zaczynają rozumieć, że stary model Europy nie ma przyszłości” (Kacewicz, 2016). Nie sposób nie dostrzec analogii z sytuacją Krymu, Osetii Południowej i Abchazji, gdyż władze moskiewskie wielokrotnie akcentowały ich prawo do „samostanowienia”, zgodne z zasadami prawa międzynarodowego i poszanowania „suwerennej” decyzji społeczeństw powyższych obszarów, czego przykładem był także sposób demonstrowania przez rosyjską telewizję obrazu referendum w Hiszpanii w sprawie niepodległości Katalonii (Stasiński, 2017). Jednocześnie na tożsame sugestie opuszczenia przez niektóre regiony administracyjne Federacji Rosyjskiej Kreml reaguje niezwykle agresywnie, traktując takie próby separatyzmów jako próbę rozbijania Rosji przez wrogów zewnętrznych, a szczególnie Stany Zjednoczone. Rosyjską taktykę dokładnie określił politolog Siergiej Markow, blisko powiązany z Putinem. 
W jego opinii, w kwestii potencjalnego opuszczenia Federacji Rosyjskiej przez jej dany region, powinna obowiązywać zasada wzajemności w odniesieniu do separatyzmów zachodnich. Markow stwierdza: „Jeśli Zachód zgodzi się na to, że mieszkańcy obwodów charkowskiego, dniepropietrowskiego, zaporoskiego mają prawo wyjść z Ukrainy, mieszkańcy Katalonii z Hiszpanii, Walonii z Belgii, wtedy i my zaakceptujemy takie zasady" (Problemy Europy - tym lepiej dla Rosji, 2016). Akcentowanie kwestii suwerenności ma w założeniu nie tylko usprawiedliwić rosyjską politykę międzynarodową, ale przede wszystkim podkreślać, że narody innych krajów mają prawo decydowania o własnym losie i do nieingerowania sił zewnętrznych w przebieg powyższych głosowań. Wypowiedzi rosyjskich urzędników o tym, że decyzja została suwerennie podjęta przez Brytyjczyków, z jednej strony mają poprawić nadszarpnięty obraz Rosji z powodu aneksji Krymu oraz wojny na Ukrainie, a z drugiej - podkreślić, że w XXI wieku idea integracji europejskiej nie jest skuteczna.

$\mathrm{Z}$ niniejszym wątkiem wiąże się inny argument, podnoszony przez moskiewskie elity polityczne, a mianowicie różnice oczekiwań zachodnich społeczeństw w odniesieniu do europejskich polityków, szczególnie unijnych urzędników. Niniejszego problemu dotyka szef komisji spraw zagranicznych Dumy Konstantin Kosaczow. W jego przekonaniu Brexit jest skutkiem różnicy oczekiwań występujących pomiędzy urzędnikami unijnymi a obywatelami UE dostrzegającymi niekorzystne skutki procesu integracyjnego (Brexit of Minor, 2016). Powyższe stwierdzenie wskazuje przede wszystkim na fakt, że Unia Europejska, zdaniem Moskwy, jest skupiona wyłącznie na dbaniu o interesy elit, zapominając o rosnących oczekiwaniach społeczeństw, co wiąże się pośrednio z trwającym od 2008 r. kryzysem ekonomicznym. Oczekiwania te, pojawiające się pod wpływem ubóstwa, wzrostu bezrobocia (szczególnie wśród młodych, które np. w Grecji, w Hiszpanii czy Włoszech oscyluje w granicach 25-50\%; Rybicka, 2015), wywołały niechęć do unijnych urzędników, którym przypisuje się winę za powstały stan rzeczy. Pojawiające się m.in. w Hiszpanii „ruchy oburzonych” (Zerka, 2012, s. 155-175) jawnie deklarują niechęć do Unii Europejskiej, wskazując na rosnącą rolę biznesu, zachodnich korporacji oraz wąkich elit politycznych w polityce mocarstw europejskich. Przedstawiciele takich ugrupowań podkreślają postępującą degradację Europy Zachodniej, która w ich mniemaniu zapomina o ludziach potrzebujących i wykluczonych. Zyskujące na znaczeniu m.in. zjawisko prekariatu (Kołek, Prekariat jako nowa klasa społeczna) oraz niezdolność UE jego rozwiązania intensyfikują niechęć młodych obywateli do szeroko pojętych instytucji unijnych. W tym kontekście nie sposób nie zauważyć, że procesowi rozmijania się oczekiwań społeczeństw w tym aspekcie sprzyja także niechęć do imigrantów, obwinianych 
w dużej mierze za liczne problemy ekonomiczne dotykające Europy Zachodniej. Niejednokrotnie oskarżani są oni o to, że odbierają miejsca zatrudnienia autochtonicznym mieszkańcom, m.in. w Wielkiej Brytanii, w której obok Niemiec występuje ich największe skupisko. Wszystkie wymienione uwarunkowania są skrzętnie wykorzystywane przez Kreml, który niejednokrotnie podkreślał, że w Rosji podobne problemy nie występują, a społeczeństwo jest jednolite i zwarte (Cheda, 2015). Media rosyjskie oraz ważniejsi politycy tego kraju podnoszą, że - w odróżnieniu od Unii Europejskiej - organizacje ponadnarodowe, skupione na obszarze postradzieckim i szerzej azjatyckim (WNP, Szanghajska Organizacja Współpracy), działają na zupełnie innych zasadach. W samych dokumentach traktatowych rzeczonych zrzeszeń możemy przeczytać, że ich działalność jest oparta głównie na kwestiach ekonomicznych i poszanowaniu, „suwerenności” ustroju wszystkich członków, a głównym czynnikiem destrukcyjnym jest terroryzm, separatyzm oraz ekstremizm (Perkowska, 2010, s. 59). Ekspansja Rosji wobec obszaru postradzieckiego oraz azjatyckiego, realizowana za ich pośrednictwem, staje się coraz atrakcyjniejszą alternatywą dla zmagającej się z licznymi trudnościami Europy Zachodniej. Podkreślił to m.in. były ambasador USA w Rosji Michael McFaul, stwierdzając, że „Europa staje się coraz słabsza, a Rosja, jej sprzymierzeńcy i wielostronne organizacje integrują się i przyciągają nowych członków" (Byty ambasador USA wyjaśnit, dlaczego Brexit powinien cieszyć Putina, 2016).

Kreml poprzez Brexit chce również uświadomić obywatelom samej Federacji Rosyjskiej, że ze względu na niedostateczne i spóźnione reakcje Zachodu na kryzys imigracyjno-uchodźczy w Rosji żyje się bezpiecznie według konserwatywnych wartości. Jeszcze przed ostatecznym głosowaniem w sprawie Brexitu rosyjski analityk Siergiej Utkin stwierdził, że oficjalna rosyjska propaganda próbuje swoim obywatelom powiedzieć, że w Rosji żyje się lepiej niż w „zgniłej Europie”, pogrążonej w kryzysie imigracyjnym oraz wyzwaniach związanych z bezpieczeństwem (zob. For Russia, Brexit Would be an Opportunity not a Tragedy). Formalnie opierając swoją politykę na konserwatywnych wartościach, kultywowanych przez m.in. Cerkiew prawosławną rządzoną przez patriarchę Cyryla (Pacepa, 2015), Kreml dąży do przekonania własnej opinii publicznej, że w Rosji panuje porządek moralny, w odróżnieniu od Zachodu, w którym zwyciężyła nadmierna tolerancja wobec szeregu innych „odmienności”, czego dowodem są słowa prezydenta Putina (Reid, 2017). Szeroko akcentowany był także wątek błędnej polityki nadmiernej otwartości kanclerz Merkel wobec niedostatecznie kontrolowanej fali emigrantów, naruszających europejskie wartości, wywołującej w UE rozliczne problemy kulturowe, którym organizacja ta, ze względu na skostniałe procedury biurokratyczne, konieczność uwzględniania interesów wielu jej podmiotów czy nierozwiązane pro- 
blemy leżące u źródeł kryzysu na Bliskim Wschodzie i w Afryce, nie jest w stanie podołać. Kreml podkreśla, że niezdolność Unii do integrowania muzułmańskich emigrantów w europejskich społecznościach jest powodowana problemami wewnętrznymi tej organizacji i brakiem w jej szeregach charyzmatycznych liderów, reprezentujących antyimigrancki punkt widzenia. Deprecjonując w rosyjskiej propagandzie znaczenie UE jako uzależnionej od USA struktury politycznej, Moskwa oraz podległe jej media manifestują narastające problemy w jej funkcjonowaniu, sugerując wręcz możliwy w najbliższym czasie rozpad wspólnoty, tożsamy $\mathrm{z}$ rozpadem ZSRR (zob. Kiedy i dlaczego się rozpadnie Unia Europejska?).

Dla Kremla Brexit stanowi dogodną możliwość nie tylko osłabienia Unii Europejskiej, ale jest okazją do podejmowania negocjacji z członkami UE, np. z Niemcami czy z Francją, jedynie na płaszczyźnie bilateralnej. Zdając sobie sprawę z ograniczeń dla Rosji w przypadku konieczności prowadzenia polityki wobec 27 członków Unii jako całości, Kreml dąży do poprawienia relacji z najważniejszymi jej graczami, mając świadomość, że część państw „starej UE” dąży do zniesienia przynoszących im wielomilionowe straty sankcji wobec Rosji, czego dowodzą wypowiedzi zachodnich polityków, m.in. przedstawicieli Ruchu Pięciu Gwiazd we Włoszech (zob. Włoski polityk: sankcje wobec Rosji szkodza samemu Zachodowi). W myśl kremlowskiej taktyki, Niemcy, Francja, Włochy, Holandia, Belgia czy Grecja stanowią grupę państw „odpowiedzialnych” i skłonnych do dialogu z Rosją. Przeciwieństwo ich stanowią „niedojrzałe” kraje Europy Wschodniej, w tym Polska, w łonie których „rusofobia” i niczym nieuzasadniona niechęć wobec rosyjskich władz i samej Rosji w ogóle rzekomo przybiera wiodącą postać we wzajemnych kontaktach. Niniejsze stwierdzenia popiera prokremlowski analityk Aleksiej Mukhin. Uważa on, że podział Europy jest korzystny dla Rosji, która efektywniej może rozmawiać z poszczególnymi jej podmiotami niż z Brukselą (Mirovalev, Baculinao, 2016). Prezydent Federacji Rosyjskiej, w reakcji na wypowiedź Camerona, że „Brexit nie wpłynie na unijną politykę sankcji wobec Rosji” (Putin do Camerona: takie wypowiedzi świadcza o niskim poziomie kultury politycz$n e j, 2016)$, oraz z osobistym zadowoleniem z faktu opuszczenia unijnych struktur przez Zjednoczone Królestwo, spodziewa się jednak w przyszłości uznania Rosji jako równoprawnego ze Stanami Zjednoczonymi gracza i potwierdzenia wiodącej roli Federacji Rosyjskiej na obszarze postradzieckim, a przynajmniej zastopowania dalszego rozszerzania NATO na Wschód, o Ukrainę i Gruzję. Poparcie powyższych starań potwierdzają liczne wypowiedzi zachodnich decydentów, m.in. Sigmara Gabriela, wicekanclerza Niemiec, czy także byłego ministra spraw zagranicznych, a obecnego prezydenta tego kraju, Franka Waltera Steinmeiera, akcentujących właśnie kluczową rolę Rosji w obecnych konfiguracjach międzyna- 
rodowych oraz konieczność przestrzegania ustaleń szczytu NATO-Rosja z roku 1997. Rozwiązania szczytu Sojuszu w Warszawie, w aspekcie militarnym, pomimo podjęcia decyzji o wprowadzeniu stałej rotacyjnej obecności wojsk amerykańskich w Polsce oraz w krajach bałtyckich, w rzeczywistości realizowały dość kompromisową ofertę wobec Rosji. Ponadto wznowienie po blisko dwuletniej przerwie rozmów multilateralnych NATO-Rosja może być sygnałem do powolnego odbudowywania przez kraje zachodnie kontaktów z Moskwą. Chociaż nie należy spodziewać się natychmiastowych efektów tych pertraktacji, to prawdopodobne jest, że z czasem Rosja ponownie zostanie uznana przez wszystkie siły międzynarodowe jako partner niezbędny w procesach rozwiązywania wszystkich bieżących światowych problemów, co już jest obecne w kontekście konfliktu syryjskiego.

Biorąc pod uwagę rosnącą pozycję ruchów społecznych oraz partii politycznych reprezentujących nurty antyislamistyczne i skrajnie prawicowe m.in. we Francji (Front Narodowy) czy w Niemczech (Alternatywa dla Niemiec), nie ulega wątpliwości, że władze w Moskwie wykorzystują na coraz większą skalę te ugrupowania do szerzenia i utrwalania swoich poglądów w Europie. Według poszlak, powyższe ugrupowania są współfinansowane pośrednio przez Kreml (Nowicki, 2015). W związku z powyższym wydaje się uzasadnione stwierdzenie, że opuszczenie przez Brytyjczyków Unii Europejskiej, przyczyni się nie tylko do wzrostu skłonności do dialogu części państw starej Unii z Rosją, ale spowoduje też, że będą one mniej zainteresowane m.in. konfliktami, w które zaangażowane jest państwo rosyjskie, np. o Górski Karabach, na Ukrainie oraz w Syrii, oraz innymi projektami integracyjnymi na obszarze postradzieckim, jak np. programem Partnerstwa Wschodniego (Chauskovsky, 2016). Dla Kremla zmaterializowanie tych scenariuszy może być okazją do zrealizowania powrotu do składu XIX-wiecznego „koncertu mocarstw”, będącego wówczas uosobieniem dominacji na kontynencie europejskim. Ze względu na liczne ograniczenia rosyjskie w sferze militarnej oraz niski poziom życia przeciętnego Rosjanina, Kreml w obecnej dobie nie dąży do wojskowej dominacji w Europie. Przejawia za to pragnienia ograniczenia roli międzynarodowej państw postkomunistycznych, szczególnie Polski i krajów bałtyckich, będących jego zdaniem hamulcowymi w procesie zbliżenia UE z Rosją. Z tego względu Brexit może oznaczać także pomniejszenie wypracowanej do tej pory pozycji wyżej wymienionych krajów.

Po trzecie wreszcie, Kreml szacuje, że za sprawą wyniku wspólnotowego referendum zostanie osiągnięty cel, o którym jeszcze przywódcy ZSRR marzyli od 1945 r. - osłabienie przymierza anglo-amerykańskiego. Sojusz obu tych państw w Europie, w Azji oraz na Bliskim Wschodzie wybitnie nie jest na rękę państwu rosyjskiemu, gdyż zaszłości historycznej obecności Brytyjczyków na wymienionych 
obszarach przyczyniają się do wzmocnienia tam amerykańskich wpływów. Umiarkowany konserwatyzm polityki byłego brytyjskiego premiera Davida Camerona względem Rosji i wstrzemięźliwość w znoszeniu wobec niej sankcji uwarunkowane zostały m.in. zamordowaniem w Londynie w listopadzie 2006 r. Aleksandra Litwinienki (obywatela Wielkiej Brytanii), wcześniej oficera FSB, utrudniając Kremlowi propagandowe oddziaływanie w krajach Unii Europejskiej. Potwierdzają to słowa jednego z rosyjskich ekspertów Aleksandra Baumowa, formułującego pretensje rosyjskiej dyplomacji do UE. W jego opinii nie jest ona samodzielna i podejmuje wszystkie ważniejsze decyzje pod presją amerykańską. Ponadto analityk stwierdza, że w UE zbyt duży głos mają „małe” kraje z Europy Wschodniej. Konkludując, Baumow podnosi, że Londyn „okazuje się najbardziej skłonny do przysłuchiwania się lękom polityków z Europy Wschodniej i krajów bałtyckich, obawiających się zagrożenia ze strony Rosji” i dlatego Unia bez Wielkiej Brytanii będzie wygodniejszym dla Kremla partnerem (Radziwinowicz, 2016). Poza tym dla ekipy poprzednika obecnego prezydenta USA Wielka Brytania, obok Niemiec, była najważniejszym orędownikiem reprezentowania interesów Ameryki w Europie. Za rządów premiera Tony’ego Blaira zdecydowanie poparła amerykańskie naloty na pozycje Państwa Islamskiego w Syrii oraz wielokrotnie opowiadała się za odsunięciem od władzy syryjskiego prezydenta Baszara El-Asada, co stoi w sprzeczności z polityką rosyjską względem niego. Zdając sobie sprawę z faktu, że zmaterializowanie scenariusza Brexitu doprowadzi do wymiany rządu w Wielkiej Brytanii, Kreml przewidywał, że nowa brytyjska ekipa rządząca będzie próbowała podjąć wysiłki wybicia się na niezależność od amerykańskiej polityki zagranicznej.

Okazją do rozbicia anglo-amerykańskiego sojuszu stały się również wybory prezydenckie w Stanach Zjednoczonych. Nie bez racji analitycy międzynarodowi uważali, że Brexit może wzmocnić poparcie Trumpa reprezentującego prawicowy elektorat, rozczarowany także w Europie dotychczasowym funkcjonowaniem Unii Europejskiej i stanem amerykańskich oraz europejskich elit politycznych. Trump w swojej retoryce opowiadał się za znaczącym osłabieniem amerykańskiego wsparcia dla NATO, uważając Sojusz za przeżytek zimnej wojny (Milewski, 2016), sugerując wówczas jednocześnie, że w przypadku jego wyboru na prezydenta rozważy uznanie Krymu jako terytorium Rosji oraz zniesienie sankcji wobec Moskwy (Pager, 2016). Amerykański miliarder, wielokrotnie wcześniej sygnalizujący stopniowy izolacjonizm Stanów Zjednoczonych oraz wolę dojścia do porozumienia z Putinem, mógłby, jak sądzono, przyczynić się do osłabienia relacji brytyjsko-amerykańskich. Nie ulega wątpliwości, że pomimo nieuniknionego już wyjścia Wielkiej Brytanii z UE Londyn w dalszym stopniu będzie mniej lub bardziej powiązany - geograficznie, gospodarczo, politycznie i kulturowo - z Eu- 
ropą Zachodnią i będzie reprezentował zachodni punkt widzenia w stosunkach międzynarodowych, co może dla Trumpa stanowić pewien problem w budowie poprawnych relacji Anglii z USA. Mimo że oba kraje łączy wspólnota interesów transatlantyckich, nie można w dłuższej perspektywie wykluczyć wzajemnej rywalizacji tych mocarstw o wpływy na terytoriach dawnego brytyjskiego imperium kolonialnego w Azji (np. Indie, Irak). Ponadto, co zrozumiałe, Stany Zjednoczone za sprawą brytyjskiego głosowania będą miały znacząco ograniczony wpływ na podejmowane przez Wspólnotę decyzje.

Niezwykle interesujące w analizie skutków Brexitu, aczkolwiek nieco w cieniu, jest zagadnienie bliskowschodnie, szczególnie konflikt w Syrii. Jakkolwiek Rosjanie wycofali znaczną część kontyngentu wojskowego z tego kraju, to w dalszym ciągu opowiadają się za utrzymaniem u władzy prezydenta Asada. Do czynników bliskowschodnich odwołuje się m.in. Mark Kennedy. Jego zdaniem, trzy czynniki mogą spowodować, że Brexit zakończy się rosyjską porażką: wykorzystanie wyników tego głosowania do podjęcia reform strukturalnych przez Unię Europejską, ale przede wszystkim intensyfikacja naboru do formacji wojskowych w krajach, głównie sunnickich, walczących z Państwem Islamskim, oraz związanego z tym zobowiązania się ogólnie pojętego Zachodu do pozbycia się zarówno Asada, jak i Państwa Islamskiego (Kennedy, 2016). Uzasadniona wydaje się więc hipoteza, że wyjście Wielkiej Brytanii z UE będzie skutkowało koniecznością zacieśnienia kontaktów amerykańsko-rosyjskich w procesie rozwiązania napięć w Syrii. Potwierdzeniem powyższego są regularne spotkania - zarówno za rządów prezydenta Obamy, jak i Donalda Trumpa - najważniejszych urzędników oraz wojskowych z obu krajów w celu rozwiązania konfliktu w Syrii. Innymi słowy, w obliczu osłabienia pozycji Państwa Islamskiego m.in. w Mosulu oraz napięć związanych z Brexitem USA, a co za tym idzie ich państwa sojusznicze, zmuszone zostały podjąć pewną formę współpracy z Rosją, która po prawie 20 latach izolacji powróciła na Bliski Wschód i powoli zdobywa pozycję porównywalną z czasami ZSRR. Wzrost znaczenia Federacji Rosyjskiej w tym regionie dowodzi, że Syria, Irak oraz Iran stopniowo zacieśniają swoje kontakty polityczne i gospodarcze z Rosją, czego dowodzić może np. fakt udostępnienia przez Irańczyków bazy wojskowej dla rosyjskich samolotów bombardujących Syrię pomimo sprzeciwów niektórych przedstawicieli irańskiej ekipy rządzącej (Karami, 2016). Prezydent Putin w czasie wizyty w Egipcie w lutym 2015 r. podpisał także umowę precyzującą zasady współpracy gospodarczej pomiędzy oboma państwami (Russia's Putin in Cairo for Talks with Egypt's Sisi, 2015). Należy stwierdzić, że dalsze pogłębianie napięć w Europie i w USA, związane bezpośrednio z opuszczeniem UE przez Brytyjczyków, spowodowało swoistą utratę wiarygodności krajów zachodnich w oczach państw Bliskie- 
go Wschodu (Egipt, Irak, Turcja, Arabia Saudyjska) i oznacza dalsze zacieśnienie ich kontaktów z Kremlem, który zdaje sobie sprawę, że każdy kolejny zamach terrorystyczny dokonywany przez islamskich terrorystów w Europie będzie oznaczał odejście części europejskich polityków od dotychczasowej proimigranckiej polityki i zwrot w stronę ugrupowań populistycznych i antyimigranckich, co realnie wpłynie na konfiguracje układu sił politycznych w Europie, ale także na Bliskim Wschodzie.

$\mathrm{Na}$ politykę rosyjską wpłynął również nieudany przewrót wojskowy w Turcji z lipca 2016 r. Nie należy zapominać, że w ostatnim czasie, po okresie napięcia w stosunkach rosyjsko-tureckich, spowodowanych zestrzeleniem przez Turków samolotu, prezydent Turcji Recep Erdoğan publicznie wyraził „ubolewanie” z powodu tej tragedii. Jest to wyraźny gest ze strony tureckiego prezydenta, który w obliczu rosnących oskarżeń o rządy autorytarne, przyczynienie się do kryzysu imigracyjnego w Europie Zachodniej oraz o wspieranie Państwa Islamskiego potrzebował poparcia ze strony innych państw. Teza o przeorientowaniu kursu polityki tureckiej na zbliżenie z Rosją okazała się słuszna. Należy pamiętać, że armia turecka jest drugą co do wielkości w NATO i jawny alians z Moskwą może jednak zostać źle odebrany zarówno w Europie, jak i za oceanem. Z drugiej jednak strony pojawiające się w dalszym ciągu doniesienia z Ankary odnośnie do przywrócenia kary śmierci i stosowania przemocy wobec uczestników i zwolenników puczu oraz innych ugrupowań opozycyjnych mogą stać się pretekstem do ostatecznego zerwania przez Erdoğana nieskutecznych jak do tej pory rokowań w sprawie przystąpienia Turcji do UE i oddalenia się tego kraju od struktur zachodnich. Spotkanie Putina z Erdoğanem w Sankt Petersburgu, w czasie którego turecki prezydent publicznie nazwał go swoim przyjacielem, ogłaszając jednocześnie nowy etap we wzajemnych relacjach, może - mimo wzajemnej rywalizacji obu państw - stanowić dla Erdoğana okazję do szantażowania krajów zachodnich, które w przypadku braku ustępstw wobec Turcji m.in. w sprawie wiz oraz imigrantów mogą stanąć w obliczu sojuszniczych relacji drugiej armii w NATO z państwem uznającym Sojusz za głównego wroga (Bielicki, 2016, s. 75, Concept of the Foreign Policy of the Russian Federation Approved by President of the Russian Federation V. Putin on 12 February 2013; Russian General Calls for Preemptive Nuclear Strike Doctrine Against NATO). Zastanawiający jest też fakt, że w połowie lipca 2016 r. do Ankary przybył Aleksander Dugin (Clowes, 2011, s. 45-49), główny ideolog wyznawanego przez Putina eurazjatyzmu, reprezentujący neoimperialistyczny punkt widzenia, oparty na prawdziwej mieszance imperializmu, prawosławia, nacjonalizmu i ekspansjonizmu. Występując wówczas na żywo na konferencji prasowej, transmitowanej przez państwową turecką telewizję, starał się przedstawić postęp 
w stosunkach między oboma krajami. Zdaniem Dugina, „Rosja i Turcja mają wspólnego wroga - Stany Zjednoczone oraz islamski ekstremizm jako instrument ich polityki" (zob. Turcja: Dugin na konferencji prasowej w Ankarze)'. Geopolityk uważa, że USA jest zwolennikiem powstania niepodległego państwa kurdyjskiego, co stoi w sprzeczności z przekonaniami zarówno Rosji, jak i Turcji (Putin's advisor: Ties with Turkey Will Be Better than Before, 2016). Jest całkiem prawdopodobne, że Turcja, która dąży do zdobycia mocarstwowej pozycji zarówno na Bliskim Wschodzie, jak i w Europie, może wykorzystać zamieszanie spowodowane Brexitem do zrealizowania własnych interesów politycznych, a także straszyć Zachód możliwością zbliżenia z Rosją w przypadku niechęci zachodnich decydentów do uznania roli Turcji jako znaczącego uczestnika procesów międzynarodowych na kontynencie europejskim. Niewątpliwie jest to istotne w kontekście uwarunkowań ekonomicznych Brexitu, które mogą dla Federacji Rosyjskiej okazać się korzystne w długofalowej perspektywie.

\section{Uwarunkowania gospodarcze Brexitu dla Rosji}

Pod kątem zjawiska Brexitu warto również spojrzeć szerzej na możliwe implikacje decyzji Brytyjczyków dla rosyjskiej gospodarki, która silnie dotknięta już sankcjami ekonomicznymi ze strony Stanów Zjednoczonych, może pogrążyć się w jeszcze większej niż dotychczas recesji. Według opinii szefa Sbierbanku Germana Grefa, wyrażonej w połowie 2016 r., systemowi gospodarczemu Rosji groziła recesja o 1 procent $\mathrm{PKB}$, a przewidywania spadku wartości akcji rosyjskich firm sięgały 5-10\% (Szef Sbierbanku: Brexit bytby złą wiadomością dla gospodarki Rosji, 2016). W obliczu przedłużenia sankcji Moskwa liczyła w pierwszej połowie 2017 r., że w dobie rosnących napięć politycznych w Europie, powodowanych Brexitem, nastąpi znaczące złagodzenie nałożonych sankcji, co jednak nie urzeczywistniło się do dnia dzisiejszego. Problem sankcji oraz Brexitu ściśle wiązano z cenami ropy naftowej. Według Antona Siłuanowa, ówczesnego rosyjskiego ministra finansów, wynik referendum oznaczał spadek cen czarnego paliwa, osłabienie rubla oraz wzrost wahań na rynkach finansowych. Siłuanow prognozował jednak, że turbulencje na rynkach będą o wiele mniejsze niż w przeszłości, a Brexit będzie miał stosunkowo ograniczony wpływ na dynamikę rozwoju gospodarczego kraju (Rosja: Brexit oznacza spadek rubla i cen ropy, 2016). Inaczej problem rozpatrywał Andriej

${ }^{1}$ Co ciekawe, to sam Putin stoi osobiście za otwarciem w Moskwie biura Partii Niepodległości Kurdystanu i przez pewien czas reprezentował nieprzejednane stanowisko wobec Ankary. 
Wiernikow, zastępca dyrektora generalnego ds. analiz inwestycyjnych Zurich Capital Management, którego zdaniem wolumen rosyjskiego handlu z Wielką Brytanią jest nieznaczny, a recesja w Europie i spadek popytu na rosyjskie surowce nie jest katastrofalnym scenariuszem (zob. Rosyjska gospodarka może skorzystać na Brexicie).

Nie brakowało też głosów, że w rosyjskim interesie jest, aby Unia była ekonomicznie stabilna. Taki pogląd prezentowała m.in. Alina Polyakowa, zastępczyni dyrektora Rady Dinu Patriciu Eurasia Center at the Atlantic Council. Jej zdaniem, silna gospodarczo Europa jest Rosji potrzebna, gdyż ma kupować od Rosji ropę i gaz (Salinas, 2016). Zwolennicy tego poglądu wykazują, że przed aneksją Krymu i wojną na Ukrainie Rosja, za sprawą swojej supremacji energetycznej na europejskiej arenie, miała zwiększone możliwości ekonomicznego oddziaływania na nią. Dlatego zaostrzanie napięć międzynarodowych i Brexit pojmowany jako początek rozpadu UE może nie być dla Rosji korzystny. Wypada zaznaczyć, że o ile konsekwencje odłączenia Wielkiej Brytanii od struktur europejskich będą dla Rosjan mało zauważalne, to problem pojawia się w kontekście rosyjskich interesów z państwami „zaprzyjaźnionymi” w UE, np. z Holandią lub Cyprem. Co ciekawe, w tym ostatnim kraju po wybuchu kryzysu finansowego w 2008 r. Moskwa na ratowanie zgromadzonych tam swoich aktywów finansowych musiała wyłożyć 2,5 miliarda dolarów, a w rajach podatkowych pod jurysdykcją brytyjską Rosjanie zgromadzili blisko 61 miliardów dolarów. Same inwestycje na Cyprze stanowią niemal 20 miliardów, a w Holandii ponad 19 miliardów dolarów (Cheda, 2016). Dla Kremla problemem mogą być również możliwe turbulencje w działalności londyńskiego City, które od wielu lat jest finansowym centrum operacji ekonomicznych przedsiębiorstw finansowanych przez Moskwę, m.in. Gazpromu, Rosnieftu, Lukoilu czy Transnieftu, które deponują tam swoje obligacje (Cheda, 2016). Ograniczenie działalności wyżej wymienionych przedsiębiorstw, borykających się ze sporymi trudnościami ekonomicznymi spowodowanymi sankcjami po aneksji Krymu i wojnie na wschodzie Ukrainy, może oznaczać dodatkowe problemy. Mogą się one objawiać w dalszym wstrzymaniu przez Kreml określonych projektów, m.in. gazociągu South Stream, czy wzmocnieniu finansowania przez państwo bieżących wydatków powyższych spółek (Ćwiek-Karpowicz i in., 2015, s. 86).

Kolejnym aspektem Brexitu w obszarze gospodarczym, podnoszonym przez rosyjskie media, jest możliwość poprawienia relacji handlowych pomiędzy Rosją a Wielką Brytanią. Interesująca jest w tej mierze analiza dyrektora Rosyjsko-Brytyjskiej Izby Handlowej (RBCC) Alana Thompsona. Wyraził on nadzieję, że po opuszczeniu UE Brytyjczycy będą bardziej skłonni do zintensyfikowania relacji 
handlowych z Rosją obecnych przed 2014 r., gdyż „mogą [one] odgrywać aktywną rolę we wzroście gospodarczym Rosji” (zob. Brexit opens Door for Stronger Russia-UK Trade Ties). Powielając (chociaż nie wprost) tezy rosyjskiej propagandy, uznającej UE za terytorium będące pod amerykańskim parasolem ochronnym, słowa Thompsona są jednym z przejawów wyrażanych przez Kreml nadziei, że wyjście Wielkiej Brytanii ze struktur europejskich umożliwi Moskwie ekspansję na brytyjski rynek i przywróci wcześniejsze związki gospodarcze. Sytuację najlepiej opisuje fakt, że według ambasady rosyjskiej w Londynie bilans handlowy pomiędzy Wielką Brytanią a Rosją zmniejszył się w 2015 r. prawie o połowę, straty wyniosły zaś 10 miliardów dolarów (Brexit opens Door for Stronger Russia-UK Trade Ties). W świetle powyższych konstatacji należy stwierdzić, że obecnie trudno trafnie przewidzieć wszystkie konsekwencje natury ekonomicznej dla rosyjskiej gospodarki obejmujące wyjście Wielkiej Brytanii z UE. Nieco łatwiejsza ocena takich skutków dotyczyć będzie dziedzin dotykających sfer szeroko rozumianego przemysłu obronnego i wojskowości.

\section{Aspekt militarny Brexitu dla Rosji}

Winniśmy w niniejszych rozważaniach zwrócić także uwagę na wymiar, który dla Moskwy może okazać się niekorzystny w dłuższej perspektywie czasowej. Nie ulega wątpliwości, że wyjście Wielkiej Brytanii z UE może doprowadzić do wzmocnienia pozycji NATO w globalnym systemie bezpieczeństwa. Według Daniela Kochisa, głównym fundamentem bezpieczeństwa europejskiego nie jest brukselska biurokracja, lecz amerykańska siła wojskowa w Europie, która ze względu na pojawiające się napięcia w stosunkach USA z UE,

może jeszcze istotniej przybrać na znaczeniu (Kochis, 2016). Również były dowódca NATO James Stavridis zdaje się to wyraźnie potwierdzać, mówiąc, że Brexit może doprowadzić do zwiększenia rangi Sojuszu (Cohen, Browne, 2016). Jeśli rzeczywiście miałoby się tak stać, to niniejsza wiadomość zwiastować może dla Moskwy poważne komplikacje. NATO, określane w kolejnych strategiach bezpieczeństwa Federacji Rosyjskiej jako przeciwnik, stanowi przede wszystkim zagrożenie nie tyle militarne, co przeszkodę w utrzymaniu wpływów na obszarze postradzieckim. Dla Kremla nie tyle wstąpienie Ukrainy czy Gruzji do UE, ale przede wszystkim ich członkostwo w NATO oznacza możliwość utraty obszarów będących od wieków w rosyjskiej strefy wpływów. Dlatego ustalenia szczytu NATO w Warszawie z lipca 2016 r. zostały przez Moskwę przyjęte z niepokojem, pomimo ich kompromisowego charakteru. Przyjrzyjmy się im nieco bliżej. 
Po pierwsze, zdecydowano się rozmieścić na obszarze Polski i państw bałtyckich cztery grupy batalionowe (amerykańska w Polsce, niemiecka na Litwie - z udziałem żołnierzy z państw Beneluxu oraz Francji i Norwegii; kanadyjska na Łotwie z udziałem Polski, Portugalii, Francji oraz Włoch; brytyjska w Estonii we współpracy z żołnierzami duńskimi). Obecność tych grup ma charakter „stałej rotacyjnej obecności" (zob. Szczyt NATO w Warszawie. Najważniejsze ustalenia). Po drugie, Sojusz zwiększa aż trzykrotnie (do 40 tysięcy) liczebność sił natychmiastowego reagowania. Jest to skonkretyzowana wersja ustaleń przyjętych na wcześniejszym szczycie w Newport. Po trzecie wreszcie, potwierdzono gotowość dowództwa obrony przeciwrakietowej NATO, dotyczącej budowy w Polsce i w Rumunii tarczy antyrakietowej. Potwierdzono także aspiracje Gruzji do Sojuszu, stwierdzając, że „Gruzja jest na dobrej drodze do NATO”, oraz opracowano specjalny pakiet dla Ukrainy, składający się z „40 przedsięwzięć” mających dostosować Ukrainę do uczestnictwa w Pakcie (zob. Szczyt NATO w Warszawie. Najważniejsze ustalenia). Nie podjęto jednak konkretnych decyzji odnośnie do przystąpienia tych krajów do NATO, co stanowi pewien sukces rosyjskiej dyplomacji, której apele o nieprzyjmowanie nowych krajów do Sojuszu są powtarzane regularnie od zakończenia zimnej wojny, a szczególnie od zapoczątkowania drugiej kadencji Putina na urzędzie prezydenta, podobnie jak zastrzeżenia co do rozpoczętej przez George’a Busha dyskusji o budowie tarczy antyrakietowej, która zdaniem rosyjskiego przywódcy zagraża bezpieczeństwu jego kraju. Zaznaczmy, że pełna gotowość systemu obrony przeciwrakietowej NATO zostanie ogłoszona po zakończeniu budowy instalacji systemu w Rędzikowie (Blacharz, 2016).

Z punktu widzenia rosyjskiej polityki niezwykle ważne jest także ogłoszenie przez NATO cyberprzestrzeni jako nowego obszaru operacyjnego działań Sojuszu, będącego w kontrze do niezwykle intensywnych działań strony rosyjskiej w tej materii. Ma on w swoim głównym założeniu nawiązywać do raportu Strategic Communications Centre of Excellence, który precyzuje znaczenie mediów społecznościowych w możliwej wojnie hybrydowej (Postanowienia szczytu NATO $w$ Warszawie to nie tylko wschodnia flanka, 2016). Działające od stycznia $2014 \mathrm{r}$. Centrum, sygnatariuszami powstania którego były Niemcy, Włochy, Wielka Brytania, Polska oraz kraje bałtyckie, ma poprawić komunikację strategiczną pomiędzy poszczególnymi członkami Sojuszu. Główną przesłanką jego działalności jest wspieranie polityki Komitetu Militarnego NATO, przeciwdziałanie wojnie hybrydowej oraz szeroko zakrojona inwigilacja social mediów wykorzystywanych na ogromną skalę w jej propagowaniu, a także badanie rosyjskich kampanii propagandowych i, szczególnie do niedawna, analiza metod propagandowych Państwa Islamskiego w Europie i jego wpływu na społeczeństwa europejskie (About us, 2016). 


\section{Zakończenie}

Odpowiedź na pytanie, czy Federacja Rosyjska zyska, czy straci na Brexicie, pozostaje złożona i dalece niesprecyzowana. Wydaje się jednak, że skutki decyzji obywateli Zjednoczonego Królestwa mogą wpłynąć na wzmocnienie roli Federacji Rosyjskiej na arenie międzynarodowej. Wynik głosowania stał się zachętą do podjęcia podobnych kroków w innych krajach Wspólnoty, gdzie zjawisko eurosceptycyzmu występuje coraz silniej, umiejętnie podsycane przez wschodnią, wysoce dofinansowaną propagandę. Właściwym przykładem są separatystyczne dążenia hiszpańskiej prowincji - Katalonii. Rosjanie, w celu rozbijania wszelkich form prozjednoczeniowych, zręcznie wykorzystują wybory prezydenckie oraz parlamentarne, czego przykłady mogliśmy zaobserwować w okresie ostatnich lat od Ameryki po kraje Europy, gdzie ingerencje w proces wyborczy na wielu poziomach były przez nich w mniejszym lub większym stopniu rozgrywane na swoją korzyść. Istniały poważne obawy, częściowo zmaterializowane, przed objęciem władzy lub przynajmniej zwiększeniem wpływu na życie publiczne, szczególnie w Niemczech, we Francji czy w USA ugrupowań i ludzi, którzy wyrażają poglądy skrajnie nacjonalistyczne i antyimigranckie. Scenariusze pisane przez Kreml zakładają uświadomienie wewnętrznej i międzynarodowej opinii publicznej konieczności współdziałania z Rosją i rozwiązywania wspólnie z nią problemów o charakterze regionalnym i globalnym, np. na Bliskim Wschodzie (Bielicki, 2016, s. 80). Z drugiej strony, Brexit może wywołać poważne implikacje w rosyjskiej gospodarce. Putin, świadom zacofania technologicznego oraz wszechobecnej korupcji, zdaje sobie sprawę, że wydarzenie to może jeszcze bardziej pogrążyć stan rosyjskiej gospodarki, ale może też wymusić konieczność podjęcia zdecydowanych reform, opracowanych przez Kudrina. Realizując wizję polityki ekonomicznej byłego szefa KGB oraz sekretarza generalnego KC KPZR Jurija Andropowa (Borogan, Sołdatow, 2015), rosyjski prezydent dostrzega, że nie przynosi ona wymiernych pozytywnych rezultatów. Pomimo faktu, że poparcie społeczne dla Putina w dalszym ciągu utrzymuje się na poziomie blisko $80 \%$ (zob. Rosja: Jedna Rosja udzieliła poparcia Putinowi w wyborach prezydenckich), to jest ono jednak uwarunkowane także stanem zasobności rosyjskiego społeczeństwa, dla którego przedłużający się stan obecny może naruszyć dotychczasową wiarę w rosyjskiego prezydenta. W każdym przypadku Brexit może oznaczać poważne zmiany na arenie globalnej, a Federacja Rosyjska jako jeden z głównych podmiotów może poważnie przewartościować obecnie istniejące sojusze międzynarodowe. 


\section{Bibliografia:}

About us. (2016). Pobrane z: http://www.stratcomcoe.org/about-us.

Bielicki, P. (2016). Strategia komunikacyjna polityki Federacji Rosyjskiej. Arcana, 1/2(127/ /128), 67-86.

Blacharz, A. (2016). Szczyt NATO: Wstępna gotowość bojowa tarczy antyrakietowej Sojuszu. Pobrane z: http://www.nowastrategia.org.pl/szczyt-nato-wstepna-gotowosc-bojowatarczy-antyrakietowej-sojuszu/.

Borogan, I., Sołdatow, A. (2015). Jurij Andropow - idol putinowskiego KGB. Pobrane z: https://histmag.org/Jurij-Andropow-idol-putinowskiego-KGB-11240.

Brexit of Minor Risks for Russia - Russian Finance Ministry. (2016). Pobrane z: http://tass. $\mathrm{ru} / \mathrm{en} / \mathrm{politics} / 884325$.

Brexit Opens Door for Stronger Russia-UK Trade Ties. (2016). Pobrane z: https://www. rt.com/business/349140-russia-uk-brexit-prospects/.

Była ambasador USA wyjaśniła, dlaczego Brexit powinien cieszyć Putina. (2016). Pobrane z: http://pl.sputniknews.com/polityka/20160626/3255465/mcfaul-putin-brexit.html.

Chausovsky, E. (2016). How Russia Will Use Brexit to Fight Sanctions. Pobrane z: https:// www.stratfor.com/analysis/how-russia-will-use-brexit-fight-sanctions.

Cheda, R. (2016). Rosja i Brexit, czyli Polska na dwa fronty. Pobrane z: http://gf24.pl/ wydarzenia/swiat/item/218-rosja-i-brexit-czyli-polska-na-dwa-fronty.

Cheda, R. (2015). Rosja największym wygranym kryzysu migracyjnego? Podzielona Europa jest Kremlowi na rękę. Pobrane z: https://wiadomosci.wp.pl/rosja-najwiekszym-wygranymkryzysu-migracyjnego-podzielona-europa-jest-kremlowi-na-reke-6025255817532545a.

Clowes, E.W. (2011). Russia on the Edge - Imagined Geographies and Post-Soviet Identity. New York: Cornell University Press.

Cohen, Z., Browne, R. (2016). Why Brexit Could Hurt America's Security and Help Russia's. Pobrane z: http://edition.cnn.com/2016/07/01/politics/eu-referendum-putin-uk-brexit-us-security/.

Concept of the Foreign Policy of the Russian Federation Approved by President of the Russian Federation V. Putin on 12 February 2013. (2013). Pobrane z: http://archive.mid.ru//nsosndoc.nsf/1e5f0de28fe77fdcc32575d900298676/869c9d2b87ad8014c32575d9002b$1 \mathrm{c} 38$ ? OpenDocument.

Ćwiek-Karpowicz, J., Dudzińska, K.I., Dyner, A.M., Kaca, E., Kościński, P., Piotrowski, M.A., Radziejowska, M., Rostowska, M., Secrieru, S., Szylar, M., Worobiow, J. (2015). Sankcje i Rosja. Pobrane z: https://www.pism.pl/files/?id_plik=19044.

For Russia, Brexit would be an opportunity not a tragedy. (2016). Pobrane z: https://www.theguardian.com/world/2016/may/19/for-russia-brexit-would-be-an-opportunity-not-a-tragedy.

Kacewicz, M. (2016). Brexit i zadymy we Francji ciesza Rosjan. Pobrane z: http://www.newsweek.pl/swiat/brexit-rosyjska-propaganda-cieszy-sie-z-wyjscia-wielkiej-brytanii-zue,artykuly,387413,1.html.

Kiedy i dlaczego rozpadnie się Unia Europejska? (2015). Pobrane z: https://pl.sputniknews. com/opinie/20150711659327/. 
Kochis, D. (2016). Brexit jest Putinowi nie na rękę. Pobrane z: http://www.kresy.pl/publicystyka,opinie?zobacz/brexit-jest-putinowi-nie-na-reke.

Kołek, A. (2018). Prekariat jako nowa klasa społeczna. Geneza, istota, wyzwania, s. 1-14. Pobrane z: https://www.academia.edu/6012350/Prekariat_jako_nowa_klasa_spo\%C5\% 82eczna._Geneza_istota_wyzwania.

Mirovalev, M., Baculinao, E. (2016). Russia, China See Silver Linings After U.K.'s Brexit Vote. Pobrane z: http://www.nbcnews.com/storyline/brexit-referendum/russia-chinasee-silver-linings-after-u-k-s-brexit-n602451.

Nowicki, M. (2015). Francuska prawica za kremlowskie pieniądze. Pobrane z: http://www. newsweek.pl/swiat/jak-rosyjskie-wladze-finansowaly-francuski-front-narodowynewsweek-pl,artykuly,360640,1.html.

Pacepa, I. (2015). The Secret Roots of Liberation Theology, National Rewiew Online. Pobrane z: http://www.nationalreview.com/article/417383/secret-roots-liberation-theology?tar get=author\&tid=901039.

Perkowska, A. (2010). Szanghajska Organizacja Współpracy. Geopolityka, Economy and Management, 3, 58-74.

Postanowienia szczytu NATO $w$ Warszawie to nie tylko wschodnia flanka. (2016). Pobrane z: https://www.wprost.pl/szczyt-nato/10014425/Postanowienia-szczytu-NATO-wWarszawie-to-nie-tylko-wschodnia-flanka.html.

Problemy Europy? Tym lepiej dla Rosji. (2016). Pobrane z:

http://kulturaliberalna.pl/2016/07/05/siergiej-markow-wywiad-putin-brexit-nato/.

Putin do Camerona: takie wypowiedzi świadcza o niskim poziomie kultury politycznej. (2016).

Pobrane z: http://wiadomosci.onet.pl/swiat/prezydent-rosji-skomentowal-brexit-nawetstraszenie-rosja-nie-pomoglo/z6q5df.

Putin's Advisor: Ties with Turkey Will Be Better Than Before. (2016). Pobrane z: http://www. dailysabah.com/diplomacy/2016/07/16/putins-advisor-ties-with-turkey-will-be-better -than-before.

Radziwinowicz, W. (2016). Po Brexicie Moskwa czeka na Trumpa. Pobrane z: http://wyborcza.pl/1,75399,20298879, rosyjska-duma-chce-specjalna-uchwala-podziekowac-brytyjczykom.html.

Reid, G. (2017). European Court Condemns Russia's Gay Propaganda Law. Pobrane z: https:// www.hrw.org/news/2017/06/22/european-court-condemns-russias-gay-propaganda-law.

Rosja: Brexit oznacza spadek rubla i cen ropy. (2016). Pobrane z: http://www.bankier.pl/wiadomosc/Rosja-Brexit-oznacza-spadek-rubla-i-cen-ropy-3549698.html.

Rosyjska gospodarka może skorzystać na Brexicie. (2016). Pobrane z: http://pl.sputniknews. com/gospodarka/20160626/3260217/brexit-rosyjska-gospodarka.html.

Russian General Calls for Preemptive Nuclear Strike Doctrine Against NATO. (2019). Pobrane z: http://www.themoscowtimes.com/business/article/russian-general-calls-forpreemptive-nuclear-strike doctrine-against-nato/506370.html. 
Rybicka, A. (2015). Zatrważające bezrobocie wśród młodych Europejczyków. Bruksela oferuje programy aktywizacji zawodowej. Pobrane z: http://www.dw.com/pl/zatrwa\%C5\% BCaj\%C4\% 85ce-bezrobocie-w\%C5\%9Br\%C3\%B3d-m\%C5\%82odych-europejczyk\%C3\%B3w-bruksela-oferuje-programy-aktywizacji-zawodowej/a-18641589.

Salinas, M.A. (2016). Brexit's Impact on Russia Stirs Concern. Pobrane z: http://www.voanews. com/content/brexit-impact-russia-stirs-concern/3396142.html.

Stasiński, M. (2017). Kampania dezinformacyjna w Katalonii była prowadzona z Rosji. http://wyborcza.pl/7,75399,22643774, madryt-przekonuje-ze-kampania-dezinformacyjna-w-katalonii-byla.html.

Szczyt NATO w Warszawie. Najważniejsze ustalenia. (2019). Pobrane z: http://wyborcza. pl/1,75398,20380134,szczyt-nato-w-warszawie-najwazniejsze-ustalenia.html.

Szef Sbierbanku: Brexit byłby zła wiadomością dla gospodarki Rosji. (2016). Pobrane z: http:// www.polskieradio.pl/42/273/Artykul/1632863,Szef-Sbierbanku-Brexit-bylby-zlawiadomoscia-dla-gospodarki-Rosji.

Turcja: Dugin na konferencji prasowej w Ankarze. (2016). Pobrane z: http://xportal.pl/? $\mathrm{p}=26230$.

Udział mocarstw zachodnich w konferencji paryskiej - zasłoną dymną dla kontynuowania polityki agresji. Gromyko piętnuje próby bezprawnej ingerencji USA i W. Brytanii w wewnętrzne sprawy krajów demokracji ludowej. (2019). Trybuna Ludu, 164(864), 2-3.

Wtoski polityk: sankcje wobec Rosji szkodza samemu Zachodowi. (2016). Pobrane z: https:// pl.sputniknews.com/polityka/201611294317642-Wlochy-Rosja-sankcje-Luigi-Di-Maio/.

Zerka, P. (2012). Hiszpański ruch 15-M: Tożsamość projektowa in statu nascendi. Kwartalnik Kolegium Ekonomiczno-Społecznego Studia i Prace, 3, 155-175. 